\title{
The failure probability of grass erosion due to wave overtopping. A case study of the Afsluitdijk, The Netherlands.
}

\author{
Jord J. Warmink ${ }^{1, a}$, Vera M. Van Bergeijk ${ }^{1}$, Martijn Kriebel ${ }^{1,2}$, Hizkia Trul ${ }^{2}$, Coen Kuiper², Suzanne J.M.H. Hulscher ${ }^{1}$ \\ ${ }^{1}$ University of Twente, P.O. Box 217, 7500 AE Enschede, The Netherlands \\ ${ }^{2}$ Witteveen+Bos, Leeuwenbrug 8, 7411 TJ Deventer, The Netherlands
}

\begin{abstract}
Wave overtopping is one of main failure mechanism of flood protective structures. Experiments and numerical simulations have shown that transitions are weak spots for cover erosion. Transitions in geometry and in bed roughness affect the cover erosion significantly by local deceleration and acceleration of the flow. This paper presents a method to compute the critical average overtopping discharge for a complex dike geometry, including transition, applied to the Afsluitdijk case study. The results show that although the critical overtopping discharge decreases with increasing wave height, the sensitivity of the critical overtopping discharge for wave height decreases for higher waves. This is shown for both the COM and the VE-TM models for all locations along the dike's cross section. Although further validation of both models is needed for a wider range of dike configurations, the results show that both models are able to probabilistically assess grass erosion based on the critical overtopping discharge for complex dike geometries, including transitions.
\end{abstract}

\section{Introduction}

Grass erosion due to wave overtopping on the crest and inner slope of dikes is one of the main failure mechanisms of sea defences. The probability of failure of the grass cover layer for a certain grass quality is determined based on the combination of significant wave height and average overtopping discharge. However, this relationship is only established for wave heights up to 3 meters. Currently, a new design is being finalized for the Afsluitdijk, which is one of the primary flood defences in the Netherlands. The normative significant wave height exceeds the maximum wave height for which the probability of failure due to grass erosion is defined in the Dutch safety standards (ENW 2017). The goal of this study is to find the relationship between the significant wave height and the critical average overtopping discharge for wave heights above 3 meters.

Several objects and transitions are located on the Afsluitdijk (Figure 1). The Afsluitdijk contains a highway and biking path, resulting in cover type transitions between grass and asphalt. These roads are located on berms leading to slope changes, which are classified as transitions in geometry. Experiments and numerical studies have shown that transitions are weak spots for cover erosion, affecting the failure probability (Steendam et al., 2014; Aguilar-López et al., 2018; Bomers et al., 2018). Therefore, a method is required to determine the failure conditions of complex flood defences that accounts for the effects of transitions.

\footnotetext{
${ }^{\mathrm{a}}$ Corresponding author: j.j.warmink@utwente.nl

DOI 10.3311/FLOODRisk2020.1.22
}

This paper presents a method to compute the critical average overtopping discharge for a complex dike geometry, such as the Afsluitdijk (Section 2). In this study, we compare the cumulative overload method (COM, Van Hoven 2015) with the coupled crest-inner slope velocity equations (VE, Van Bergeijk et al. 2019a) and the transition model (TM; Hoffmans 2012; Van Bergeijk et al. 2019b). The critical discharge is calculated at every transition for various significant wave heights with these two modelling approaches (Section 3). The model results are compared to the results of the field tests with the wave overtopping simulator (Bakker et al., 2009). The conclusions are stated in Section 5.

\section{Methods}

A method is developed to determine the critical overtopping discharge for grass erosion on complex flood defences. The general approach is discussed followed by a short description of the two modelling approaches used in this study. Both approaches include the effect of transitions on grass erosion.

\subsection{Study area: the Afsluitdijk}

The Afsluitdijk is a primary flood defence separating the Wadden Sea (for which the highest hydraulic loads are 


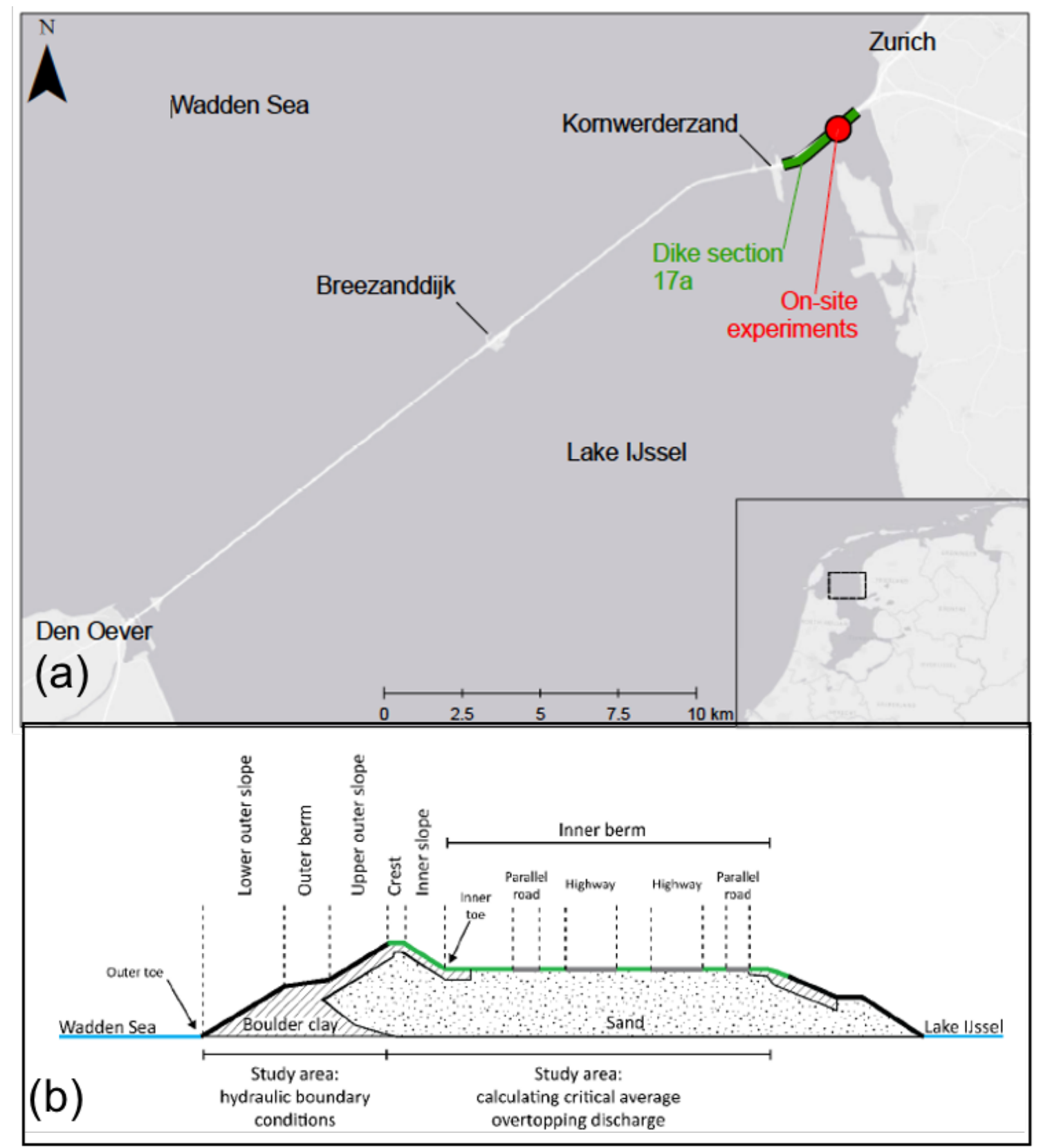

Figure 1: (a) The location of the Afsluitdijk with the studied dike section and the location of the on-site experiments. (b) Cross-sectional schematization of the studied dike section where the cover consists of asphalt (grey), other nonerodible material (black) and grass (green). Adapted from Kriebel (2019).

experienced) from the Lake IJssel (Figure 1). The dam is non-uniform over the total length of 32 kilometres, thus, the dam is separated in 17 dike section in which the hydraulic load and dam strength are approximately constant.

Experiments with the Wave Overtopping Simulator were carried out at dike section 17 a to study the strength of the grass cover on the Afsluitdijk (Bakker et al., 2009). The experiments were performed with significant wave heights of 2 meters at two test sections: one with a complete grass covered profile and one section where a road was located $3 \mathrm{~m}$ from the inner toe (Bakker et al., 2009). Erosion was observed for an overtopping discharge of $10 \mathrm{l} / \mathrm{s} / \mathrm{m}$ at the inner toe and $50 \mathrm{l} / \mathrm{s} / \mathrm{m}$ on the inner slope at the first test section. The road at the second test section was damaged for an overtopping discharge of $30 \mathrm{l} / \mathrm{s} / \mathrm{m}$ while the inner toe was again damaged at $10 \mathrm{l} / \mathrm{s} / \mathrm{m}$.

\subsection{Cumulative overload method (COM)}

The cumulative overload method is the official method for dike design in the Netherlands and it is able to take the effects of transitions into account. The method calculates the damage number $D$ based on the flow velocity on the crest $U_{0}$ and the critical flow velocity $U_{c}$ (Van der Meer et al., 2010).

$D=\sum \alpha_{M}\left(\alpha_{a} U_{0}\right)^{2}-\alpha_{s} U_{c}^{2}$ for $\alpha_{M}\left(\alpha_{a} U_{0}\right)^{2}>\alpha_{s} U_{c}^{2}$

The three $\alpha$ actors account for transitions. The load factor $\alpha_{M}$ accounts for an increasing load due to turbulence 

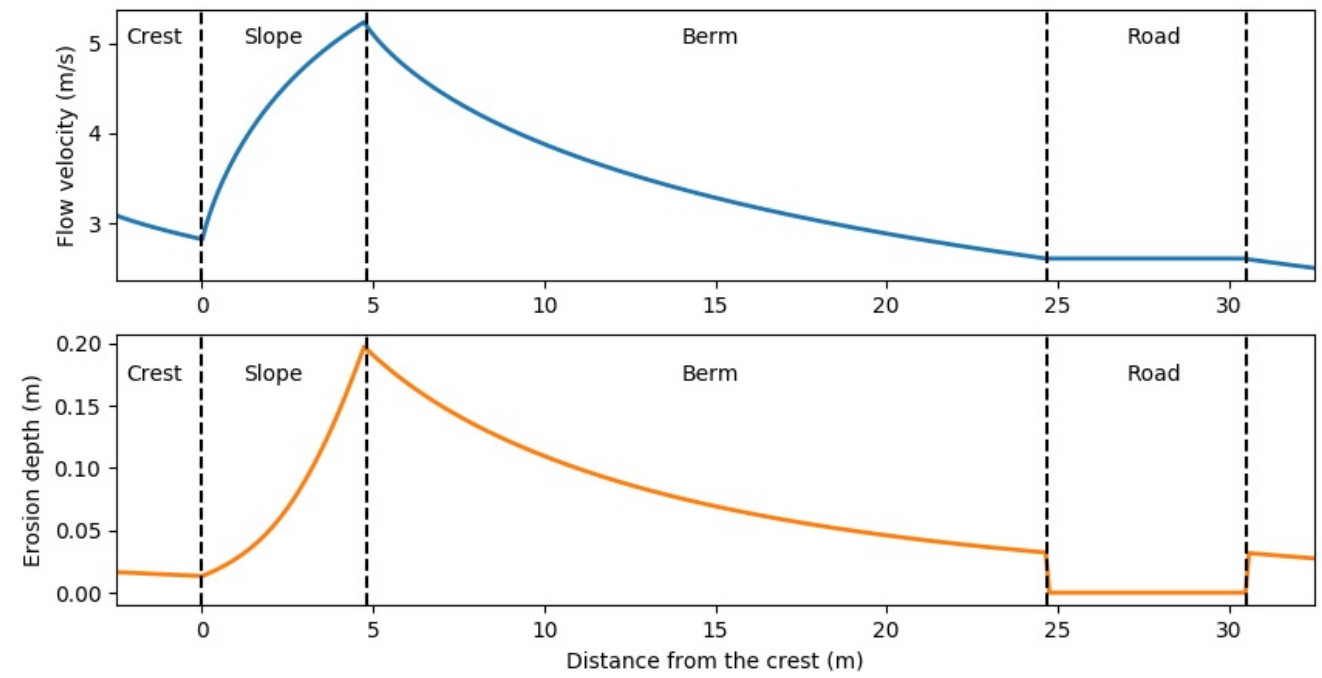

Figure 2: The 2\% exceedance flow velocity and the total erosion depth during a storm along the profile of the Afsluitdijk with the VE-TM method.

at transitions. The acceleration of the wave on the inner slope is described by the acceleration factor $\alpha_{a}$ and the decrease in grass strength at transitions is included as factor $\alpha_{s}$ (Van Hoven \& Van der Meer, 2017).

Table 1: The load factor $\alpha_{M}$, the strength factor $\alpha_{s}$ and the acceleration factor $\alpha_{a}$ at the studied locations for the COM method. Adapted from Kriebel (2019).

\begin{tabular}{|l|l|l|l|l|}
\hline Location & Description & $\alpha_{\mathrm{M}}$ & $\alpha_{\mathrm{s}}$ & $\alpha_{\mathrm{a}}$ \\
\hline 1 & $\begin{array}{l}\text { Hard cover material outer } \\
\text { slope - grass cover crest }\end{array}$ & 1.0 & 0.9 & 1.0 \\
\hline 2 & Crest - inner slope & 1.0 & 1.0 & 1.0 \\
\hline 3 & Inner slope & 1.0 & 1.0 & 1.4 \\
\hline 4 & Inner toe & 1.2 & 1.0 & 1.4 \\
\hline 5 & Grass berm - asphalt road & 1.0 & 0.9 & 1.2 \\
\hline 6 & Asphalt road - grass berm & 1.7 & 0.9 & 1.0 \\
\hline
\end{tabular}

The values of the factors at the studied locations (Table 1) are adapted by Kriebel (2019) based on Van der Meer \& Van Hoven (2014). The critical velocity was set to 6.5 $\mathrm{m} / \mathrm{s}$ as estimated by Van Hoven (2015). The grass cover has failed when the damage number exceeds the critical value of $7000 \mathrm{~m}^{2} / \mathrm{s}^{2}$.

\subsection{Combined velocity - erosion model (VE-TM)}

The analytical formulas of Van Bergeijk et al. (2019) describe the flow velocity along a dike profile. These formulas account for transitions in cover type by adapting the bottom friction coefficient $f$. The maximum depthaveraged velocity along complex geometries can be calculated by combining the formulas for horizontal surfaces $U_{\text {horizontal }}$ with the formula for the inner slope Uslope.

$$
\begin{aligned}
& U_{\text {horizontal }}(x)=\left(\frac{f x}{2 Q}+\frac{1}{U_{\text {horizontal }}(x=0)}\right)^{-1} \\
& U_{\text {slope }}(x)=\frac{\alpha}{\beta}+\mu \exp \left(-3 \alpha \beta^{2} \frac{x}{\cos \varphi}\right)
\end{aligned}
$$

with the cross-dike coordinate $x$, the discharge of the overtopping wave $Q$ and the slope angle $\varphi$. The parameters $\alpha, \beta$ and $\mu$ are given by

$$
\alpha=\sqrt[3]{g \sin \varphi}, \beta=\sqrt[3]{f / 2 Q} \text { and } \mu=U_{s, 0}-\frac{\alpha}{\beta}
$$

with the flow velocity at the start of the slope $U_{s, 0}$ and the gravitational acceleration $g$.

The erosion depth $z_{m}$ along the dike profile is calculated with the transition model of Valk (2009), which is an extension to the Hoffmans (2012) model, based on the shear stress $\tau$

$$
\begin{aligned}
& z_{m}(x)=T_{0}\left(\frac{\omega^{2} \tau(x)-\tau_{c}(d)}{E_{\text {soil }}(d)}\right) \text { for } \omega^{2} \tau>\tau_{c}(d) \\
& \tau(x)=\frac{1}{2} \rho f U(x)^{2}
\end{aligned}
$$

Finally, the erosion depth after a storm event is calculated by summation of the erosion depth over all waves.

\subsection{General approach for the critical overtopping discharge}

In order to estimate the total amount of damage caused by overtopping waves along the dike's cross-section, both COM and VE-TM models require the flow velocity of each individual overtopping wave at the start of the crest as input. Additionally, the geometry of the dike needs to be varied to alter the flow velocity, and consequently the amount of damage, until the critical average overtopping discharge is found. This is done using the method described by Kriebel (2019).

First, normative hydraulic conditions (water level, peak wave period and angle of wave attack) are obtained for varying significant wave heights using the procedure and software of Rijkswaterstaat (2017). The development of these hydraulic conditions throughout a storm event is schematized based on Chbab \& De Waal (2017).

The normative hydraulic storm conditions are used to calculate the $2 \%$ run-up height, which is used as input for the $2 \%$ flow velocity at the start of the crest (EurOtop Manual, 2018). The influence factors that account for the roughness of the outer slope in the equation for the $2 \%$ run-up height are based on Chen et al. (2020).

The calculated $2 \%$ run-up height, and consequently the $2 \%$ flow velocity at the start of the crest, are only valid under constant hydraulic conditions, which is not 


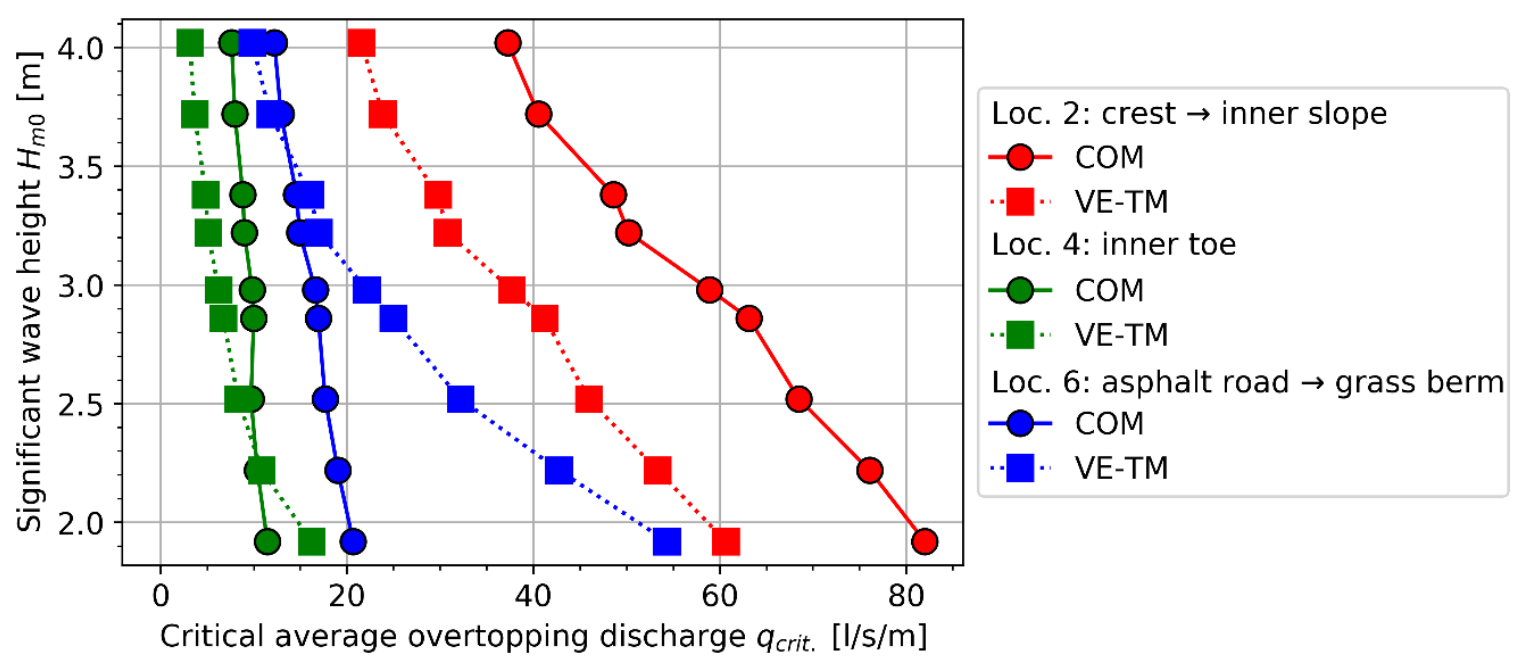

Figure 3: The relationship between the significant wave height and the critical overtopping discharge at three cross-dike locations for the COM and VE-TM model.

the case for a storm event. Therefore, the hydraulic conditions throughout the storm event are discretized in periods of one hour during which the hydraulic conditions are kept constant, which results in an hourly $2 \%$ run-up height and thus an hourly $2 \%$ flow velocity. However, both the COM and VE-TM models require the flow velocity for each individual wave. Assuming a Rayleigh distribution for the wave run-up, these variables can be calculated for each wave using the method described by Van Hoven \& Van der Meer (2017).

As the flow velocity of each overtopping wave is known, the total damage caused by the storm event is calculated and compared to the critical damage number (for $\mathrm{COM}$ ) and critical erosion depth of $0.2 \mathrm{~m}$ (for VETM; Figure 2). Following the modelling approach of Kriebel (2019), this is firstly done for a modified crosssectional design in which the crest elevation is one centimeter above the outer berm elevation. If failure of the grass cover is reached, the crest height is increased by one centimeter and the amount of damage is recalculated. This iterative process continues until no failure of the grass cover is found. The critical average overtopping discharge is determined as the overtopping discharge corresponding to the dike geometry in the previous iteration, which is calculated using the overtopping discharge equation given by Chen et al. (2020). This is done using the hydraulic conditions during the discretized period at the peak of the storm event, in line with the method of Van Hoven \& Van der Meer (2017).

\section{Results}

\subsection{Critical overtopping discharges}

The critical overtopping discharge is computed for three cross-dike locations: the transition from the crest to the inner slope, the inner toe and the transition from the asphalt road to the grass berm (location 2, 4 and 6, respectively, in Table 1). This is done for varying significant wave heights between $1.92 \mathrm{~m}$ and $4.02 \mathrm{~m}$ using the COM and VE-TM model. The critical overtopping discharge decreases for an increasing wave height and shows a large variation across the dike (Figure 3). The transition from the inner slope to the berm is weakest with a minimum critical overtopping discharge of $3.4 \mathrm{l} / \mathrm{s} / \mathrm{m}$ for a significant wave height of $4.02 \mathrm{~m}$. The locations on the crest are strongest with critical overtopping discharges exceeding $80 \mathrm{l} / \mathrm{s} / \mathrm{m}$. The critical overtopping discharge for small wave heights show more variation along the profile compared to higher wave heights for which the difference in critical overtopping discharge between, for example, the inner toe and crest is much smaller.

\subsection{Comparison of the models}

The COM model and the VE-TM model both predict that the inner toe is the weakest location with low critical overtopping discharges and that the crest is stronger with much higher overtopping discharges. The COM model predicts larger overtopping discharges at all three locations for high waves (Figure 3). However, for lower wave heights the predicted critical overtopping discharge with the VE-TM model is larger at the inner toe and the road, which shows that the VE-TM model is more sensitive for the wave height. An increase in the critical overtopping discharge is related to a lower crest height, thus a shorter slope length. The acceleration along the inner slope in the VE-TM model increases with increasing slope length, while the acceleration factor in the COM model remains constant for all slope lengths. This effect results in a larger sensitivity to the wave height in the VE-TM model. The relationship between the critical overtopping discharge and wave height develops similarly in both models for the crest location, although the predicted overtopping discharges with the VE-TM model are smaller than the COM model.

\subsection{Comparison with the overtopping field tests}

The field tests showed that the inner toe is the most vulnerable location for wave overtopping (Section 2.1) with damage starting at $10 \mathrm{l} / \mathrm{s} / \mathrm{m}$. Damage of the grass cover next to the road started at $30 \mathrm{l} / \mathrm{s} / \mathrm{m}$ and damage of the 
inner slope started at $50 \mathrm{1} / \mathrm{s} / \mathrm{m}$. The two models in this paper show the same cross-dike behavior with low critical overtopping discharges for the inner toe and higher critical discharges for the road and inner slope.

Both models predict a larger critical overtopping discharge than the value determined during the field tests at the inner toe for a wave height of $2 \mathrm{~m}$ (Figure 3). The VE-TM model predicts a larger overtopping discharge $\left(q_{\text {crit }} \approx 55 \mathrm{l} / \mathrm{s} / \mathrm{m}\right)$ and the COM model predicts a smaller overtopping discharge $\left(q_{c r i t} \approx 20 \mathrm{l} / \mathrm{s} / \mathrm{m}\right)$ compared to the measured value at the road $\left(q_{\text {crit }} \approx 30 \mathrm{l} / \mathrm{s} / \mathrm{m}\right)$ for a wave height of $2 \mathrm{~m}$. The modelled critical overtopping discharges at the inner toe are similar to the value of the field tests $\left(q_{\text {crit }} \approx 10 \mathrm{l} / \mathrm{s} / \mathrm{m}\right)$.

The goal of this study was to determine the critical overtopping discharge of wave heights up to 4 meters. The minimum critical overtopping discharge is $3.4 \mathrm{1} / \mathrm{s} / \mathrm{m}$ (COM) and $1.4 \mathrm{l} / \mathrm{s} / \mathrm{m}$ (VE-TM) for a significant wave height of 4 meters. The design wave height of the new Afsluitdijk is $3.38 \mathrm{~m}$ for dike section $17 \mathrm{a}$ which corresponds to a critical overtopping discharge of approximately $10 \mathrm{l} / \mathrm{s} / \mathrm{m}$ and $7 \mathrm{l} / \mathrm{s} / \mathrm{m}$ for the COM and the VE-TM modelling approaches, respectively.

\section{Conclusions}

We have developed a general method to compute the critical average overtopping discharge for a complex dike geometry. The method is applied to the new design of the Afsluitdijk in the Netherlands using both the COM and VE-TM models to simulate grass erosion at various crossdike locations. The results show that, although the critical overtopping discharge decreases with increasing wave height, the sensitivity of the critical overtopping discharge for wave height decreases for higher waves. This is shown by both the COM and the VE-TM models for all locations along the dike's cross section.

Both models show that the transition from the inner slope to the inner berm is be the weakest point (lowest critical overtopping discharge) in the cross section.

For smaller wave heights, the VE-TM model predicts larger critical discharges for the inner toe and the parallel road, compared to the COM model. This can be attributed to the influence of the inner slope on the hydraulic load, while the COM model uses a constant acceleration factor (independent of slope length).

Comparison with the overtopping field tests performed on the Afsluitdijk in 2009 shows the same cross-dike behavior as the model results where the inner toe is most vulnerable for grass erosion. The critical overtopping discharges for the design wave height of the new Afsluitdijk are approximately $10 \mathrm{l} / \mathrm{s} / \mathrm{m}(\mathrm{COM})$ and $7 \mathrm{l} / \mathrm{s} / \mathrm{m}$ (VE-TM).

Although further validation of both models is needed on a range of dike configurations, the results show that both models are promising in probabilistically assessing grass erosion based on the critical overtopping discharge for complex dike geometries such as the Afsluitdijk.

\section{Acknowledgements}

This work is part of the research programme All-Risk, with project number P15-21, which is (partly) financed by the Netherlands Organisation for Scientific Research (NWO). The authors are grateful to Infram for the use of the data of the overtopping experiments and the LevveL consortium for providing the concept design of the dam.

\section{References}

1. Aguilar-López, J. P., Warmink, J. J., Bomers, A., Schielen, R. M., \& Hulscher, S. J. (2018). Failure of grass covered flood defences with roads on top due to wave overtopping: a probabilistic assessment method. Journal of marine science and engineering, 6(3), 74.

2. Bakker, J. J., Mom, R. J. C. and Steendam, G. J. (2009) Factual Report: Overslagproeven en afschuifproef Afsluitdijk. Marknesse, The Netherlands: Infram.

3. Bomers, A., Aguilar-López, J.., Warmink, J. J., \& Hulscher, S. J. (2018). Modelling effects of an asphalt road at a dike crest on dike cover erosion onset during wave overtopping. Natural hazards, 93(1), 1-30.

4. Chbab, H. and De Waal, H. (2017) Achtergrondrapport Hydraulische Belastingen: Wettelijk Beoordelingsinstrumentarium 2017, Deltares Report 1230087-008-HYE-0001. Delft, The Netherlands: Deltares.

5. Chen, W., Van Gent, M. R. A., Warmink, J. J., \& Hulscher, S. J. M. H. (2020). The influence of a berm and roughness on the wave overtopping at dikes. Coastal engineering, 156, 103613.

6. ENW 2017. Fundamentals of Flood Protection. Published by the Expertise Network for Flood Protection (ENW).

7. EurOtop Manual (2018) EurOtop - Manual on wave overtopping of sea defences and related structures. www.overtopping-manual.com. Available at: www.overtopping-manual.com.

8. Hoffmans, G.J. 2012. The influence of turbulence on soil erosion. Eburon Uitgeverij BV.

9. Kriebel, M. (2019). Quantification of grass erosion due to wave overtopping at the Afsluitdijk. Master thesis, University of Twente, The Netherlands.

10. Rijkswaterstaat (2017) Hydraulische Randvoorwaarden Afsluitdijk. Utrecht, The Netherlands: Rijkswaterstaat.

11. Steendam, G. J., Van Hoven, A., Van der Meer, J. W., \& Hoffmans, G. (2014). Wave Overtopping Simulator tests on transitions and obstacles at grass covered slopes of dikes. Coastal Engineering, 1(34):79.

12. Valk, A. (2009) Wave overtopping impact of water jets on grassed inner slope transitions. Master Thesis, Delft University of Technology, The Netherlands.

13. Van Bergeijk, V.M., Warmink, J.J., Van Gent, M.R.A, Hulscher, S.J.M.H. (2019a). An analytical model of wave overtopping flow velocities on dike crests and landward slopes. Coastal engineering, 149, 28-38. 
14. Van Bergeijk, V., Warmink, J., Frankena, M., \& Hulscher, S. (2019b). Modelling dike cover erosion by overtopping waves: the effects of transitions. Coastal Structures 2019, 1097-1106.

15. Van der Meer, J.W., Hardeman, B., Steendam, G.J., Schüttrumpf, H. and Verheij, H. (2010). Flow depths and velocities at crest and inner slope of a dike, in theory and with the Wave Overtopping Simulator. ASCE, Proc. ICCE 2010, Shanghai.

16. Van Hoven, A. (2015) Memo Verdelingen kritisch overslagdebiet WTI2017, Deltares Memo 1220086005-HYE-00003. Delft, The Netherlands: Deltares.

17. Van Hoven, A., Van der Meer, J. M. (2017) Onderbouwing kansverdeling kritisch overslagdebiet ten behoeve van het OI2014v4, Deltares Report 1230090-011-GEO-0006-jvm. Delft, The Netherlands: Deltares. 